\title{
Current Challenges in the Management of Sepsis in ICUs in Resource-Poor Settings and Suggestions for the Future
}

\author{
Marcus J. Schultz, Martin W. Dünser, Arjen M. Dondorp, \\ Neill K. J. Adhikari, Shivakumar lyer, Arthur Kwizera, \\ Yoel Lubell, Alfred Papali, Luigi Pisani, Elisabeth D. Riviello, \\ Derek C. Angus, Luciano C. Azevedo, Timothy Baker, \\ Janet V. Diaz, Emir Festic, Rashan Haniffa, Randeep Jawa, \\ Shevin T. Jacob, Niranjan Kissoon, Rakesh Lodha, \\ Ignacio Martin-Loeches, Ganbold Lundeg, David Misango, \\ Mervyn Mer, Sanjib Mohanty, Srinivas Murthy, \\ Ndidiamaka Musa, Jane Nakibuuka, Ary Serpa Neto, \\ NT Hoang Mai, Binh Nguyen Thien, \\ Rajyabardhan Pattnaik, Jason Phua, Jacobus Preller, \\ Pedro Povoa, Suchitra Ranjit, Daniel Talmor, \\ Jonarthan Thevanayagam, and C. Louise Thwaites
}

M. J. Schultz (两) A. M. Dondorp · L. Pisani

Mahidol University, Bangkok, Thailand

Department of Intensive Care, Academic Medical Center, University of Amsterdam, Amsterdam, The Netherlands

M. W. Dünser

Kepler University Hospital, Johannes Kepler University, Linz, Austria

N. K. J. Adhikari

Sunnybrook Health Sciences Centre, University of Toronto, Toronto, ON, Canada

S. Iyer

Bharati Vidyapeeth Deemed University Medical College, Pune, India

A. Kwizera · J. Nakibuuka

Mulago National Referral Hospital, Kampala, Uganda 


\section{Y. Lubell}

Department of Intensive Care, Academic Medical Center, University of Amsterdam, Amsterdam, The Netherlands

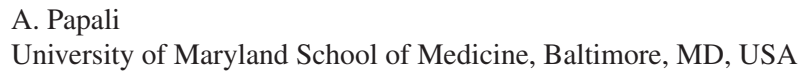

A. Papali

University of Maryland School of Medicine, Baltimore, MD, USA

Division of Pulmonary and Critical Care Medicine, Atrium Health, Charlotte, NC, USA

E. D. Riviello · D. Talmor

Beth Israel Deaconess Medical Center, Harvard Medical School, Boston, MA, USA

D. C. Angus

University of Pittsburgh, Pittsburgh, PA, USA

L. C. Azevedo

Hospital Sirio-Libanes, Saõ Paulo, Brazil

T. Baker

Karolinska Institute, Stockholm, Sweden

J. V. Diaz

California Pacific Medical Center, San Francisco, CA, USA

E. Festic

Mayo Clinic, Jacksonville, FL, USA

R. Haniffa

Mahidol University, Bangkok, Thailand

R. Jawa

Stony Brook University Medical Center, Stony Brook, NY, USA

S. T. Jacob

Liverpool School of Tropical Medicine, Liverpool, UK

N. Kissoon $\cdot$ S. Murthy

British Columbia Children's Hospital, Vancouver, BC, Canada

R. Lodha

All India Institute of Medical Science, Delhi, India

I. Martin-Loeches

St. James's University Hospital, Dublin, Ireland

G. Lundeg

Mongolian National University of Medical Sciences, Ulaanbaatar, Mongolia

D. Misango

Aga Khan University Hospital, Nairobi, Kenya

M. Mer

Johannesburg Hospital, University of the Witwatersrand, Johannesburg, South Africa

S. Mohanty $\cdot$ R. Pattnaik

Ispat General Hospital, Rourkela, Odisha, India

N. Musa

Seattle Children's Hospital, University of Washington, Washington, WA, USA

\section{A. Serpa Neto}

Department of Intensive Care, Academic Medical Center, University of Amsterdam, Amsterdam, The Netherlands

Medical Intensive Care Unit, Hospital Israelita Albert Einstein, Sao Paulo, Brazil 
NT Hoang Mai

Oxford University Clinical Research Unit, Hospital for Tropical Diseases, Ho Chi Minh City, Vietnam

B. N. Thien

Trung Vuong Hospital, Ho Chi Minh City, Vietnam

J. Phua

National University Hospital, Singapore, Singapore

J. Preller

Addenbrooke's Hospital, Cambridge University Hospitals NHS Foundation Trust, Cambridge, UK

P. Povoa

Nova Medical School, CEDOC, New University of Lisbon, Lisbon, Portugal

Hospital de Sao Francisco Xavier, Centro Hospitalar de Lisboa Ocidental, Lisbon, Portugal

S. Ranjit

Appolo Hospitals, Chennai, India

J. Thevanayagam

Mzuzu Central Hospital, Mzuzu, Malawi

C. L. Thwaites

Nuffield Department of Medicine, Centre for Tropical Medicine and Global Health,

University of Oxford, Oxford, UK

\subsection{Introduction}

In many low- and middle-income countries (LMICs), with improved public health services like sanitation and immunization, the relative importance of curative care to improve health becomes more important. This includes care for sepsis, a major reason for intensive care unit (ICU) admission in LMIC. These patients will currently often be treated in general wards, but basic intensive care facilities are becoming increasingly available. The scope of the current review is limited to the ICU setting. ICUs in resource-restricted settings have to function with important limitations, including both infrastructure and materials and human resources. It is important to address economic aspects around the provision of relatively expensive intensive care in low-income countries. Most LMICs have tropical or subtropical climates, and causes of sepsis will often be different from high-income countries (HICs), where most sepsis guidelines have been developed. Because of the different settings and the different causes of sepsis, existing guidelines will need prudent interpretation. There is a broad research agenda around this, which is currently still hardly addressed. Finally, expansion of setting-adapted training will be important to improve ICU performance in LMICs.

In this review, written by a group of physicians from resource-poor and resourcerich ICUs in LMICs and high-income countries, respectively, who were involved in the development of a series of sets of recommendations for sepsis management in resource-poor settings as recently published [1-4], the estimated burden, pathogens, 
and pathophysiology of sepsis are compared between resource-poor and resourcerich settings. The availability of critical care and guidelines and costs of critical care in LMICs are compared to that in high-income countries. Suggestions for future directions are provided.

\subsection{Burden and Causes of Sepsis and Its Management}

\subsubsection{Disease Burden}

While detailed information has been reported on the epidemiology and outcome of sepsis in HICs [5, 6], only scant systematically collected epidemiological data exist from LMICs [7, 8], despite that these countries carry about $80 \%$ of the global mortality caused by infections [9]. At present, the epidemiology of sepsis in LMICs can only be loosely estimated from the epidemiology of acute infectious diseases with a potential to cause sepsis captured in the "Global Burden of Disease" database [1012]. This database reported important regional differences in the epidemiology of such acute infectious diseases (Fig. 1.1). For instance, while the majority of acute infections in resource-limited settings are acquired in the community [9], the incidence of nosocomial infections such as catheter-related bloodstream infections or ventilator-associated pneumonia is several fold higher in LMICs than in highincome countries like the United States [13]. Similarly, only few data on sepsis mortality in LMICs have so far been published. These suggest that sepsis-related mortality greatly varies among regions and countries according to their income level. The case fatality attributable to sepsis in HICs has been decreasing over the last decades to $30-40 \%[5,6]$, whereas case fatality rates of up to $80 \%$ continue to be reported from resource-poor regions of the world [14-17].

\subsubsection{Causative Pathogens and Pathogenesis}

Although many bacterial pathogens causing sepsis in LMICs are similar to those in high-income countries, resistance patterns to antimicrobial drugs can be very different. It has been suggested that the high prevalence of multidrug-resistant bacteria, including methicillin-resistant Staphylococcus aureus, extended spectrum betalactamase-producing bacteria, carbapenamase-producing Enterobacteriaceae, and Mycobacterium tuberculosis, contributes to the excess deaths observed in LMICs caused by invasive infections with these bacteria, particularly among infants [13, 18]. Five countries with the highest burden of under five deaths (China, Nigeria, Pakistan, India, and the Democratic Republic of the Congo) also have the highest neonatal deaths from antimicrobial resistance [19]. The problems with antimicrobial resistance and its implications for the treatment of sepsis in LMICs have been described before [4].

Whereas the majority of severe sepsis in HICs is caused by bacterial infections, in LMICs, many of which are located in the tropics, causes of sepsis also include 


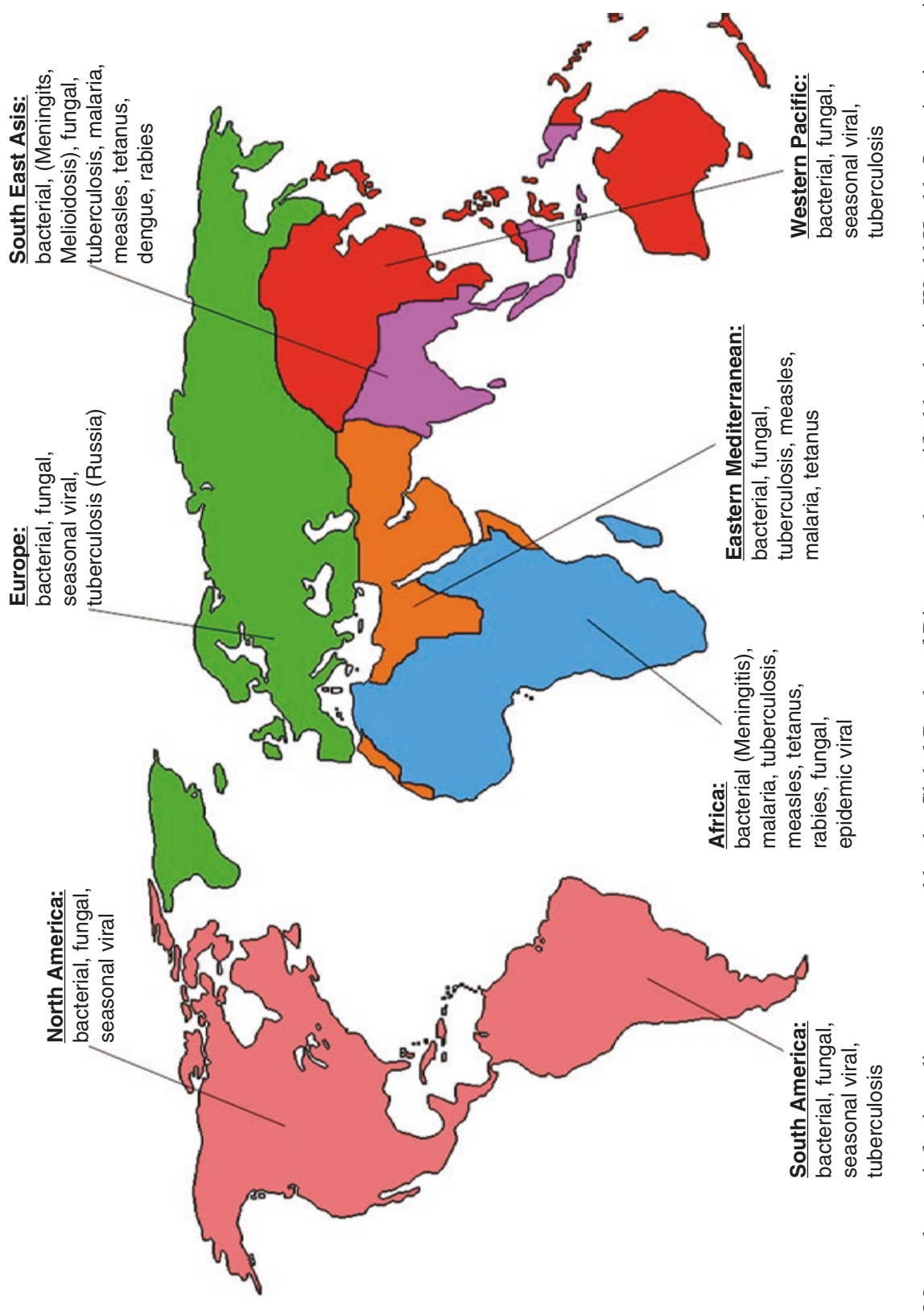


acute non-bacterial diseases, including protozoal diseases such as malaria, and viral diseases such as measles, dengue, or viral hemorrhagic fevers. The international literature mainly focuses on sepsis caused by invasive bacterial infections and the associated systemic inflammatory response [20, 21]. Therefore, non-bacterial causes are understudied, and the acquired knowledge on the pathophysiology and treatment of sepsis may not be generalizable to these other causes of sepsis [22].

Previous sepsis definitions put a large emphasis on the "dysregulated response of the host's immune system" as the key element of the pathogenesis of sepsis [23, 24]. Although this will be generally correct, it ignores potential direct damaging effects of certain pathogens or pathogen products, which can in particular play a role in tropical diseases. For instance, in severe falciparum malaria, a blocked microcirculation resulting from the sequestered infected red blood cell biomass is a direct cause of vital organ failure [25]; and in dengue shock syndrome, virus proteins are thought to directly damage the glycocalyx lining the endothelium [26, 27]. Intervening in these pathophysiological pathways will obviously require therapeutic approaches different from those in bacterial sepsis.

\subsubsection{Poor Availability of Critical Care}

There is persisting substantial heterogeneity in ICU capacity around the world. In Europe and Northern America, the ICU capacity is between 5 and 30 beds per 100,000 inhabitants. In LMICs, the scarce data available show ICU capacities that are much lower, albeit quite variable [28]. For instance, in Asia the reported ICU capacity is only 0.3 beds per 100,000 inhabitants in Bangladesh, 2.4 per 100,000 inhabitants in Malaysia, 2.5 per 100.000 inhabitants in Sri Lanka, and 3.9 per 100,000 inhabitants in China [29], but in contrast 11.7 adult and pediatric ICU beds per 100,000 inhabitants in Mongolia [30]. Studies form several countries in subSaharan Africa reported as few as 0.1-0.2 ICU beds per 100,000 inhabitants [31, 32]. With the exception of Mongolia [30] and Latin-American countries [33], almost no data on the availability of dedicated pediatric ICU capacities have been published for resource-limited settings [34].

We tend to look at LMICs as if they are "uniform," but this is a too simplistic if not naive approach. Within and between LMICs, there is an important heterogeneity in the availability of intensive care, resourcing of ICUs, quality of services, and case mix [35]. The rapidly expanding urban population in many LMICs will provide a challenge for the current urban ICU capacity because of the associated increase in case load [36].

Another problem in reporting ICU capacity is the lack of a commonly agreed definition of an ICU or ICU bed [37, 38]. The spectrum of how ICUs are staffed and equipped differs vastly between countries and regions. Table 1.1 summarizes published evidence and personal experience of the authors in an attempt to categorize different ICU structures worldwide. As surveys from various countries suggest, the availability of ICU-related material resources directly correlates with the countries' income level and healthcare spendings [7, 31, 32, 39-43]. The shortage of medical 
Table 1.1 Proposal for a categorization of intensive care units ${ }^{\mathrm{a}}$

\begin{tabular}{|c|c|c|c|c|}
\hline $\begin{array}{l}\text { Proposed } \\
\text { categories }\end{array}$ & $\begin{array}{l}\text { Category } \\
\text { I-unrestricted }\end{array}$ & $\begin{array}{l}\text { Category } \\
\text { II-moderate } \\
\text { restrictions }\end{array}$ & $\begin{array}{l}\text { Category III-severe } \\
\text { restrictions }\end{array}$ & $\begin{array}{l}\text { Category } \\
\text { IV-no } \\
\text { formal ICU } \\
\text { structure }\end{array}$ \\
\hline $\begin{array}{l}\text { Typical setting } \\
\text { (not including } \\
\text { private settings) }\end{array}$ & $\begin{array}{l}\text { High-income } \\
\text { countries }\end{array}$ & $\begin{array}{l}\text { Higher-middle- } \\
\text { income countries }\end{array}$ & $\begin{array}{l}\text { Lower-middle and } \\
\text { low-income (major } \\
\text { cities) countries }\end{array}$ & $\begin{array}{l}\text { Rural areas } \\
\text { of low- } \\
\text { income } \\
\text { countries }\end{array}$ \\
\hline $\begin{array}{l}\text { Formal ICU } \\
\text { structure/service }\end{array}$ & Yes & Yes & Partly & No \\
\hline $\begin{array}{l}\text { Availability of } \\
\text { specifically } \\
\text { trained } \\
\text { physicians and } \\
\text { nurses }\end{array}$ & Widespread & Irregular & Rare & Unavailable \\
\hline $\begin{array}{l}\text { Availability of } \\
\text { ICU equipment } \\
\text { (i.e., patient } \\
\text { monitor, } \\
\text { mechanical } \\
\text { ventilator, renal } \\
\text { replacement } \\
\text { therapy) }\end{array}$ & Unrestricted & $\begin{array}{l}\text { Moderate } \\
\text { restrictions (i.e., } \\
\text { irregular } \\
\text { maintenance of } \\
\text { equipment, } \\
\text { limited } \\
\text { availability of } \\
\text { advanced } \\
\text { treatment } \\
\text { modalities such as } \\
\text { RRT) }\end{array}$ & $\begin{array}{l}\text { Severe restrictions } \\
\text { (i.e., basic } \\
\text { monitoring typically } \\
\text { available, limited } \\
\text { number of } \\
\text { mechanical } \\
\text { ventilators, } \\
\text { widespread } \\
\text { unavailability of } \\
\text { advanced treatment } \\
\text { modalities such as } \\
\text { RRT) }\end{array}$ & Unavailable \\
\hline $\begin{array}{l}\text { Availability of } \\
\text { ICU drugs and } \\
\text { disposable } \\
\text { materials }\end{array}$ & Unrestricted & Mild restrictions & Moderate restrictions & $\begin{array}{l}\text { Severe } \\
\text { restrictions }\end{array}$ \\
\hline
\end{tabular}

Abbreviations: ICU intensive care unit, $R R T$ renal replacement therapy

${ }^{\text {aThe }}$ categories proposed here should not be seen as definite, but merely should serve as a starting point of future thinking

professionals specifically trained in the care of acutely and critically ill patients is another widespread and serious challenge for ICU services in many LMICs [31, 32, 39-42]. A notable exception to this is well-staffed and well-equipped ICUs in private healthcare facilities. Such services can typically be found in some HICs and LMICs, but these usually remain only accessible for those who can afford it.

The increasing but still low ICU capacity in poorer regions [44] implies that access to ICU services for critically ill patients is usually severely limited. This results in frequent triage decisions [32], which likely increases preventable mortality [45]. Even though costs of care in ICUs of resource-limited settings are only a fraction of those encountered in HICs [46], expenses for ICU care are usually to a large extent covered by the patient's family and relatives in LMICs. Unwanted consequences can be denial or refusal of ICU admission of poor patients, but also the premature withdrawal of lifesaving interventions [47, 48]. In other instances, costs 
of care for a critically ill patient, who may eventually die, can exceed the limited budget of many families leaving them with high debts or even causing private bankruptcy.

\subsubsection{Incomplete and Unadjusted Guidelines}

The principle of "evidence-based medicine" is equally important in resourcelimited as in resource-rich settings. Development of local evidence is important, since case mix and causes of sepsis, but also available infrastructure and facilities, are essentially different from those in HICs. Resource-limited ICUs are frequently limited in the availability of equipment, laboratory support, and skilled physician and nursing staff. As a result, recommendations on sepsis management in resource-poor settings, such as those developed by the Global Intensive Care Working Group of the European Society of Intensive Care Medicine (ESICM) [49], differ in several aspects from the Surviving Sepsis Campaign guidelines, which were developed in high-income settings [50]. Obvious examples include targeting strict blood glucose levels with insulin, which can be safe with frequent and reliable blood glucose monitoring, while it is a dangerous strategy when the effects of insulin titrations are determined infrequently or not at all. Other modifications in recommendations for sepsis management could result from differences in the availability of and indications for fluids in sepsis patients between resource-rich and resource-poor settings, but also the cause of sepsis (see also Box 1.1).

Box 1.1: Availability of and Indications for Fluids in Sepsis Patients Differ Between High-Income Countries and Low- and Middle-Income Countries Intravenous infusion of fluids is a key intervention in patients with sepsis as this syndrome frequently leads to intravascular hypovolemia from extravasation due to capillary leaking.

RESOURCE-RICH SETTINGS: physicians and nurses, independent from each other, have free and unlimited excess to fluids for intravenous infusion, which may facilitate a "too liberal" fluid approach leading to "overzealous" fluid resuscitation known to be associated with worse outcome of sepsis patients.

RESOURCE-POOR SETTINGS: usually there is a shortage of fluids for intravenous fluids, decision on the amounts of fluids to be given is restricted to attending physicians and not nurses, and the type of fluid chosen may depend on its price (e.g., dextrose-containing fluids, such as 5\% dextrose or $10 \%$ dextrose, are cheap and thus readily available, opposite to crystalloid solutions); inadequate resuscitation, either because of too low or too late given or wrong fluids infused, may worsen outcome of sepsis patients. 
FLUID THERAPY IN BACTERIAL SEPSIS: the recommendations on fluid therapy in sepsis patients are largely built on evidence coming from randomized controlled trials in patients in RESOURCE-RICH SETTINGS, where most patients do have BACTERIAL SEPSIS.

FLUID THERAPY IN NON-BACTERIAL SEPSIS: interestingly, randomized controlled trials including patients with severe falciparum malaria or dengue shock syndrome suggest more restricted fluid therapy than recommended for bacterial sepsis to be better. One major difference between BACTERIAL SEPSIS and NON-BACTERIAL SEPSIS is that fluid bolus resuscitation is not recommended in hyperlactatemic patients with severe falciparum malaria who are not hypotensive. Also, in dengue shock syndrome, proper fluid management is pivotal to ensure a good outcome; fluid therapy in dengue shock syndrome should ensure adequate circulating volume to support tissue perfusion, but avoid overfilling, which will cause interstitial edema, which is in particular harmful in the lung.

Despite the importance of building "local" evidence, many aspects of existing guidelines and basic principles of good critical care are universal. Access to adequate information has improved massively in this cyber age, and several courses (such as the BASIC for Developing Healthcare Systems courses developed by the Chinese University of Hong Kong, Hong Kong, China, and Médecins Sans Frontières) are available. Theoretical knowledge of specialist doctors in developing countries is often impressive, but translating this into practical implementation can lag behind, which is an important scope for training. Training should not only be for ICU physicians but also for nurses and other clinical personnel. It will be important that education on sepsis management does not focus only on ICU staff but includes medical schools, nursing schools, and training of other health workers, as many sepsis patients in LMICs receive treatment outside an ICU. "Train-the-trainer" models and fostering local champions for positive change are important to sustain improvements of care.

\subsection{Costs of Care in Sepsis}

\subsubsection{Expensive but Likely Cost-Effective Critical Care}

The vast resources consumed by ICUs, up to a staggering $1 \%$ of total gross domestic product in the United States [51], demand their subjection to explicit economic cost-benefit considerations [52]. The literature from high-income settings has indeed expanded over the past decade, demonstrating that many critical care interventions offer significant health returns with costs per quality-adjusted life year (QALY) gained well below a threshold of US \$50,000, indicative of a cost-effective intervention in this context. 
For countries in which more basic services are still relatively undeveloped, it might be questioned whether investment in ICUs should take priority over the strengthening of lower tiers of the healthcare system [53]. Irrespective of these considerations, the reality is that in many growing economies, ICUs are increasing in number [44], with virtually no evidence regarding the cost-effectiveness of their services.

\subsubsection{Costs of Critical Care Among Regions}

One approach is to consider the evidence from HICs, with a much lower willingness to pay the abovementioned threshold. Applying a threshold of US $\$ 4000$ per QALY gained [54] suggests that numerous ICU interventions and those for sepsis in particular [55-61] are likely to be cost-effective in ICUs in LMICs (Table 1.2). For several reasons these cost-effectiveness ratios might be conservative in the context of LMICs. First, the cost of ICUs in these countries is much lower than in HICs. The two largest standardized multicountry reviews of critical care costs in high-income settings estimated the cost per ICU day ranging from US \$850 to US \$3400 in 2015 $[63,64]$, with labor being the dominant cost driver (61\% and $67 \%$, respectively). The proportional difference in labor costs between high-income countries and LMICs will be similar to or higher than that of their respective gross domestic product per capita [65]. This alone implies that the critical care costs in LMICs will be less than a third that in HICs. Other costs, such as laboratory services (10\% of total critical care cost [64]), are also likely to be far lower for similar reasons, as well as drug costs and cost-saving practices such as recycling of consumables [66]. In one of the few costing analyses of an ICU from a LMIC, the total cost per ICU admission day in India was estimated at just over US \$200 [67], between approximately 5 and $20 \%$ that for HICs.

However, also the absolute financial outlay per intervention multiplied by the number of interventions is important to consider, in particular in LMICs. Even in a wealthy country with a high threshold, its tolerance depends exquisitely on the number of times it must spend the money, especially if up-front costs are high. In other words, an intervention might appear cost-effective, but if it would have to be applied to a massive portion of the public, the costs would still be perceived as financially impossible. This also requires there is an effective system of triage in place to see that these interventions are offered to patients who are most likely to benefit, at times a challenge in LMICs.

Finally, we are uncertain whether applying a threshold of US \$4000 per QALY gained is one that could be promoted or generalized, as there is a large intra- and inter-region variation in resources. Country- and ideally region-specific currency conversions/purchase power parity comparisons should be made. 
Table 1.2 The cost-effectiveness of interventions for the management of severe sepsis

\begin{tabular}{|c|c|c|c|c|}
\hline $\begin{array}{l}\text { Author, year } \\
\text { [Reference] }\end{array}$ & Cohorts (country) & Intervention & Conventional & $\begin{array}{l}\text { Cost/QALY } \\
\text { (in } 2015 \\
\text { US \$) }\end{array}$ \\
\hline $\begin{array}{l}\text { Huang et al. } \\
2007 \text { [57] }\end{array}$ & $\begin{array}{l}\text { Monte Carlo simulation of } \\
\text { patients with sepsis } \\
\text { undergoing EGDT beginning } \\
\text { either in the ED or ICU } \\
\text { (USA) }\end{array}$ & $\begin{array}{l}\text { EGDT in ED } \\
\text { or ICU }\end{array}$ & Standard care & $\begin{array}{l}\$ 3506- \\
8953\end{array}$ \\
\hline $\begin{array}{l}\text { Talmor } \\
\text { et al. } 2008 \\
{[61]}\end{array}$ & $\begin{array}{l}\text { Prospective cohort study of } \\
\text { patients treated with an } \\
\text { integrated sepsis protocol } \\
\text { compared to controls (USA) }\end{array}$ & $\begin{array}{l}\text { Integrated } \\
\text { sepsis protocol }\end{array}$ & Standard care & $\begin{array}{l}\$ 20,265 \\
(2015)\end{array}$ \\
\hline $\begin{array}{l}\text { Lehmann } \\
\text { et al. } 2010 \\
{[60]}\end{array}$ & $\begin{array}{l}\text { Monte Carlo simulation of } \\
\text { sepsis episodes in ICU } \\
\text { patients with use of PCR with } \\
\text { cultures to identify the } \\
\text { causative organism and } \\
\text { initiate tailored antibiotic } \\
\text { therapy (EU) }\end{array}$ & $\begin{array}{l}\text { PCR and } \\
\text { cultures }\end{array}$ & $\begin{array}{l}\text { Traditional } \\
\text { cultures only }\end{array}$ & $\$ 3798$ \\
\hline $\begin{array}{l}\text { Karlsson } \\
\text { et al. } 2009 \\
{[59]}\end{array}$ & $\begin{array}{l}\text { Prospective cohort study of } \\
\text { sepsis patients admitted to the } \\
\text { ICU who were followed for } \\
2 \text { years (Finland) }\end{array}$ & $\begin{array}{l}\text { ICU care for } \\
\text { severe sepsis }\end{array}$ & Standard care & $\$ 2664$ \\
\hline $\begin{array}{l}\text { Jones et al. } \\
2011 \text { [58] }\end{array}$ & $\begin{array}{l}\text { Prospective before-after } \\
\text { clinical trial to establish the } \\
\text { initiation of EGDT in the ED } \\
\text { prior to transfer to ICU for } \\
\text { newly admitted sepsis } \\
\text { patients (USA) }\end{array}$ & $\begin{array}{l}\text { EGDT for } \\
\text { sepsis in ED }\end{array}$ & $\begin{array}{l}\text { Standard ED } \\
\text { care for sepsis }\end{array}$ & $\begin{array}{l}\$ 6283 \\
(2015)\end{array}$ \\
\hline $\begin{array}{l}\text { Suarez et al. } \\
2011 \text { [62] }\end{array}$ & $\begin{array}{l}\text { Prospective before-after } \\
\text { clinical trial to assess the } \\
\text { impact of an educational } \\
\text { program on adherence to } \\
\text { "Surviving Sepsis Campaign } \\
\text { Guidelines" (Spain) }\end{array}$ & $\begin{array}{l}\text { Surviving } \\
\text { sepsis protocol } \\
\text { for severe } \\
\text { sepsis }\end{array}$ & Standard care & $\begin{array}{l}\$ 7810 \\
(2015)\end{array}$ \\
\hline $\begin{array}{l}\text { Assuncao } \\
\text { et al. } 2014 \\
\text { [55] }\end{array}$ & $\begin{array}{l}\text { Prospective case-control } \\
\text { analysis of patients treated } \\
\text { with EGDT vs. standard care } \\
\text { (Brazil) }\end{array}$ & EGDT & Standard care & Dominant \\
\hline $\begin{array}{l}\text { Harrison } \\
\text { and Collins } \\
2015[56]\end{array}$ & $\begin{array}{l}\text { Markov model assessing } \\
\text { cost-effectiveness of PCT as a } \\
\text { diagnostic tool for bacterial } \\
\text { infection in ICU patients } \\
\text { (USA) }\end{array}$ & PCT & $\begin{array}{l}\text { Standard } \\
\text { diagnostic } \\
\text { techniques }\end{array}$ & Dominant \\
\hline
\end{tabular}

Abbreviations: $E G D T$ early goal-directed therapy, $E D$ emergency department, $I C U$ intensive care unit, $P C R$ polymerase chain reaction, $P C T$ procalcitonin 


\subsubsection{Benefit of Critical Care Among Regions}

The mean age of adult patients admitted to ICUs in HICs is consistently higher than those reported in LMICs. For example, in European ICUs, the mean age of adult admissions is typically 55-66 years, much higher than the median age of 34 years in a Rwandan ICU [68], the mean age of 32 years in one of the few ICUs in Uganda [1], and the median age of 37, 51, and 49 years in ICUs in Bangladesh, Nepal, and India [69]. Although not specified for admission diagnoses, it likely also reflects the younger age of sepsis patients. This can be taken as an argument to invest in better intensive care to save these young lives from an in principle treatable disease. Also, in LMICs where social security networks are usually lacking, the loss of an individual's economic activity has far more extensive economic consequences for the families involved.

By generalizing the evidence from HICs and considering the lower costs and higher potential gains, there are strong indications that a wide range of critical care services are likely to be cost-effective in LMICs. Unfortunately, there is a dearth of evidence directly from these settings to confirm this. The only economic evaluation of an ICU in Bosnia and Herzegovina concluded that critical care was highly costeffective in their setting [46]. A study from Brazil showed that the implementation of a sepsis management protocol was associated with an absolute reduction of $18 \%$ in mortality and with cost savings [55].

\subsubsection{Impact of Certain Interventions Among Regions}

Despite these suggestions that a broad range of ICU services could be cost-effective in LMICs, there is also reason for caution. First, some interventions are likely to have a much lower impact in poorly functioning environments than they might have in resource-rich settings. For example, invasive monitoring in an ICU with poor basic infection control could result in more harm than benefit. For this reason it is imperative that basic standards of care are in place prior to introduction of costly interventions whose effect might otherwise be compromised. Training programs to improve the general quality of care that require no costly interventions have been shown to have beneficial effects [69]. Second, while hypothetically cost-effectiveness should correspond with affordability, in LMICs where health systems are often fragmented and divided between the private and public sector and an abundance of vertically funded health programs, this is often not the case. It is imperative therefore that only interventions with modest budgetary impacts are shortlisted for consideration and those that have the greatest beneficial effects, with the lowest incremental costs, are selected for implementation. Some such low-cost approaches have been identified and should be prioritized for evaluation. Better surveillance systems for local etiologies of sepsis and antimicrobial susceptibility patterns have been recognized as a key requirement for improving the management of sepsis and critical care [4], and a modeling-based economic evaluation supported the notion that this is likely to be highly cost-effective [70]. 
Likewise, the development and adaptation of LMIC-specific risk prediction models have been shown to potentially outperform models widely used in highincome settings like the frequently used Acute Physiology and Chronic Health Evaluation Score and the Simplified Acute Physiology Score [68], which might not even be feasible in many ICUs in LMICs. The same is true for scoring systems in children, and scoring systems that are context relevant should also be explored because the Predicted Risk of Mortality may underpredict mortality [71].

Critical care in general and a subset of specific interventions can be an efficient use of scarce resources in LMICs. But despite the aforementioned lower costs, an ICU admission, e.g., in India, would most likely represent a catastrophic expenditure consuming over half the mean annual household income [44, 67] (see also: Box 1.2). As such facilities expand in LMICs and inevitably consume increasing resources, it is imperative for health authorities to ensure these offer affordable and cost-effective services while monitoring and continuing to seek opportunities to improve the quality of critical care and their efficiency at low cost. This was exemplified by the United Kingdom in the late 1990s, where a countrywide initiative to transform and modernize critical care was associated with a $10 \%$ reduction in mortality at lower cost increases than would otherwise be expected [72].

\section{Box 1.2: Critical Care Expenditure in Indian Hospitals}

In India critical care services are offered in four broad types of hospitals, with variable reimbursements. Variable reimbursements potentially lead to a great diversity in care of the critically ill, especially those who tend to have an extended ICU stay (i.e., longer than just a view days).

GOVERNMENTAL hospitals: the ICU bed, ventilation, and basic medications may be free of costs, but patient will need to spend out of pocket for expensive medications like certain antibiotics and disposables and for the family to stay in a distinct place (far) away from their homes. Often in a few days, they will exhaust their meager finances after which their care will be compromised.

PUBLIC CHARITY TRUST hospitals, including hospitals of private medical colleges: these hospitals have a mandate to provide free treatment to patients below the poverty line. In addition, these hospitals also offer concessional treatment under various governmental insurance schemes for poor patients that, however, are mainly utilized for surgical patients and short-stay patients like myocardial infarction and stroke. The insurance offered for sepsis is very meager and cannot cover more than the first few days in ICU. Patients thus will need to spend out of pocket for expensive medications like certain antibiotics and disposables and for the family to stay in a distinct place (far) away from their homes.

PRIVATE CORPORATE hospitals: these will treat affording patients either paying out of pocket or through some form of insurance. Except for 
the rich and very rich, in a week or two, such patient will exhaust their finances and will then either be transferred to GOVERNMENTAL hospitals or PUBLIC CHARITY TRUST hospitals. These transfers however are not easy given scarcity of beds. Public charitable hospitals will generally have an admission policy that will discourage patients that are deemed unsalvageable or may require some form of limitation of therapy. GOVERNMENTAL hospitals have to accept such patients, but here the bed crunch is often more severe. This leaves patient and caregivers in a very difficult position and may lead to withdrawal of care or discharge against medical advice.

Smaller PRIVATE NURSING HOMES: these may offer critical services for selected patients, but this too follows a similar trajectory as that of the PRIVATE CORPORATE hospitals, i.e., once patients' finances are exhausted, they need to be transferred.

\subsection{Sepsis Research in Resource-Limited Settings}

\subsubsection{A Yet Largely Untouched Research Agenda}

With only $1.7 \%$ of all biomedical research publications originating in LMICs [73], and a likely even greater disparity in critical care [44], both the needs and the opportunities for critical care research are vast. Recent rigorous attempts to quantify the global burdens of sepsis, infection, and respiratory failure confirm a profound lack of epidemiologic critical illness data from LMICs, with the only reliable data limited to single-center descriptions [68, 74-77]. The International Severe Acute Respiratory and Emerging Infection Consortium (ISARIC), the Global Intensive Care Working Group of the ESICM, and the Mahidol Oxford Research Unit in Bangkok, Thailand, are three examples of groups working to create the infrastructure for global epidemiologic data on critical illness, for use both as baseline data at regular intervals and in preparation for disease outbreaks [78].

Research on infectious diseases that lead to critical illness are perhaps the most successful areas of investigation thus far, with impressive scientific advancements in diseases such as malaria, tuberculosis, and melioidosis [79-81]. Defining and testing quality metrics are an area prioritized in both critical care and global public health [82], but quality improvement in resource-limited ICUs remains largely unexplored $[44,83]$. The latter requires some ability to benchmark ICUs with severity of illness scores, also a nascent area of study [68]. Research into medical education models like the Human Resources for Health program in Rwanda [84], decision support tools like the Checklist for Early Recognition and Treatment of Acute IllNess (CERTAIN) [85], and Vital Signs Directed Therapy [86] could help in better defining how to optimize knowledge acquisition and application for providers in resource-limited settings. 


\subsubsection{Challenges with Research in Resource-Restricted Settings}

The realities of restriction in resources interact to create complex challenges to producing quality critical care research. Many short-term multisite epidemiologic studies depend on individual sites to participate without funding for the perceived minimal data collection burden. However, staff at resource-constrained sites often cannot spare even the short-term investment required to participate, and "standard" clinical data such as arterial blood gas analyses and chest radiographs are often not available at these sites $[76,78]$. Likewise, multicenter clinical trials are significantly more expensive to perform in resource-limited settings since baseline clinical or analytic infrastructure of any sort cannot be assumed. Efforts to build resource capacity in research and to ensure fair authorship opportunities also mean that research has two resourceintensive and sometimes competing goals: that of developing local researchers without prior training and that of producing high-quality research. An unintended consequence of (appropriate) increasing involvement by local institutional review boards is that lack of staffing and experience may lead to unnecessary delays in research approvals. These resource barriers to collecting epidemiologic data are exacerbated by the fact that "critical illness" is not a laboratory-defined condition but rather one that is often defined by the expensive resources used to treat it $[28,87]$.

Ethical considerations are complex as well. All participants in resource-limited settings must be considered potentially "vulnerable" populations due to extreme need and lack of health or research literacy. Deciding where equipoise exists for interventions proven to work in high-resource settings in settings of low resources is difficult. Asking the question, "How do we do this better given limited resources?" uncomfortably raises the question "How do we increase resources and to what extent are we obligated to do so?" Ethical considerations also include relationships between local and foreign researchers, the latter who often bring financial and experiential resources leading to unequal power dynamics and potential for abuse [88]. Allowing lower standards for publication for research originating in low-resource settings has been considered in order to decrease some of the publication bias toward resource-rich settings; however, it is not at all clear that publishing poorquality research that could impact clinical care is ethical or advisable.

\subsection{Suggestions for the Future}

\subsubsection{Better Definition of Sepsis}

The latest sepsis definition [89], which refers to sepsis as life-threatening organ dysfunction caused by a dysregulated host response to infection, better reflects the fact that sepsis can complicate any serious acute infection. As pointed out earlier, direct damaging effects of the pathogen itself or its products can sometimes be the main process. Consequently, research on sepsis treatment should not focus only on immunomodulating strategies in bacterial sepsis but also on faster illumination of 
the pathogen and its products, which could be in particular relevant in certain nonbacterial causes of sepsis like falciparum malaria, cryptococcal, and various viral infections.

Another unmet need is to validate the various definitions for sepsis in more varied populations, like children in LMICs, adults in LMICs, and areas where the causative pathogens of sepsis differ from Western countries where the present definitions have been developed.

\subsubsection{Better Research Infrastructures and Planning}

Experience, resources, and human power are critical for building evidence, which are not routinely available in resource-poor settings. The global critical care community should help building local clinical research capacities and contribute to obtaining adequate funding. Engagement of a variety of stakeholders, including local intensive care societies, healthcare authorities (e.g., ministries of health), and universities, will be crucial in this respect [90]. There are large funding bodies, such as the Wellcome Trust, that support several efforts, but additional funds are clearly needed. Teaming up of researchers from established groups in HICs with local groups in resource-limited settings has proven a good model, provided equal and reciprocal relationships are guaranteed. Formulating essential topics for research will be important and could benefit from increased networking between critical care physicians from developing countries. This would also foster research networks needed to perform adequately powered clinical trials. Requirements for quality clinical research are not necessarily available in many LMICs, with often little research infrastructure or human resources for research available. Hospitals and their doctors can be overburdened by their service delivery tasks, leaving little room for research. Offering a career path to clinical research physicians could free up manpower for this important aspect of improving evidence-based critical care. Priority settings and governance regarding financial resources for research and implementation projects will become extremely important. Also, local institutions, including ethical review boards, should help create an enabling environment for research benefiting the local population, and not promote unnecessary barriers, which is now at times the case.

\subsubsection{Obtaining Relevant Evidence and Adapting Guidelines}

Obtaining local intelligence on the most important causes of sepsis and the resistance patterns of the infecting microorganisms is crucial to guide local empirical antimicrobial treatment. Since microbiological capacity is often lacking in hospitals in LMICs, research collaborations could help obtaining this evidence from strategically located sentinel study sites.

We need additional recommendations for those interventions not yet covered in the published guidelines. Multicenter trials assessing clinical efficacy and 
effectiveness of new interventions and interventions known to be effective in resource-rich settings are sorely needed, given differences in epidemiologic and treatment contexts [44]. The Fluid Expansion As Supportive Therapy (FEAST) trial on fluid resuscitation in febrile African children with shock demonstrates that these trials are feasible and may yield unexpected results [91]. Networks of critical care researchers are increasingly established in more resource-limited areas of the world, which could lead to additional studies of this kind [44]. Beyond these broad areas of research, specific subtypes deserve special attention in resource-limited settings. Social determinants of disease and barriers to care are of particular relevance to all research in resource-limited settings including intensive care [82]. While costeffectiveness analyses are arguably important in all environments without infinite resources, their need is more acute in places with fewer resources to allocate [92]. Locally adapted prediction models can help ensure that interventions are targeted in a cost-effective manner.

Another important area for critical care research is on developing templates for expanding urban ICU capacity in fast-growing cities [36]. Setting-specific guidance, instead of country-specific guidance on how to build and equip an ICU probably, is an additional and substantial area of research.

Finally, research on the process whereby scientific knowledge is translated into improved quality of care, "global health delivery science," gets at the immediate challenge in patient care in resource-poor settings, the fact that so much of what is known is not implemented effectively [82].

\subsubsection{Opportunities}

While the challenges are daunting, the opportunities are similarly impressive. Outbreaks like Ebola have increased the drive for intensive care research in resourcelimited settings both by demonstrating how critical illness in these settings impacts people in resource-rich settings and by highlighting the need for improved critical care capacity in all areas of the world [93]. Interest in and funding for global health have increased steadily over the last few decades, such that career path and funding opportunities for HIC researchers are better than ever before. Researchers from resource-limited settings now also have opportunities for high-quality training and mentorship through programs, for example, through the Wellcome Trust or the UK "Medical Research Council" schemes and the American Thoracic Society's "Methods in Epidemiologic, Clinical, and Operations Research" (MECOR) program [94].

An example of building a research structure is one from India, where the Indian Society of Critical Care Medicine initiated a "cloud-based database" called "Customized, Health in Intensive care, Trainable Research, and Analysis (CHITRA)" (http://www.isccm.org/chitra.aspx).

Finally, LMICs and HICs could mutually benefit from their research agendas; HICs also gain from more LMIC research. For example, LMIC considerations about direct pathogen effects could, in turn, generate better critical thinking about 
sepsis, from which both HICs and LMICs gain. Similarly, technologic innovation under resource constraints can yield gains for all. Critical care could be ripe for this at times called "frugal innovation" or "reverse innovation" concept [95]. Also, in our personal experience [69], nurses from HICs who have worked in LMICs, and even for a short time, are more cost-conscious than their colleagues.

\subsection{Conclusions}

Strategies to improve the quality of sepsis management in resource-poor settings require consideration of disease-specific and setting-specific factors and meticulous evaluation of the best way to adapt and deploy quality improvement initiatives. Critical care, including sepsis management, is expensive but likely cost-effective in LMICs, but we need to better understand what the true financial impact of critical care is, both at a macro- and micro-economy level. Sepsis management in resourcelimited settings is a largely unexplored frontier with a clear mandate and exciting opportunities for impact.

Acknowledgments All authors of this chapter are members of the Global Intensive Care Working Group of the European Society of Intensive Care Medicine. The authors thank the Working Group and the Society for their support.

\section{References}

1. Kwizera A, Festic E, Dunser MW. What's new in sepsis recognition in resource-limited settings? Intensive Care Med. 2016;42(12):2030-3.

2. Musa N, Murthy S, Kissoon N. Pediatric sepsis and septic shock management in resourcelimited settings. Intensive Care Med. 2016;42(12):2037-9.

3. Serpa Neto A, Schultz MJ, Festic E. Ventilatory support of patients with sepsis or septic shock in resource-limited settings. Intensive Care Med. 2016;42:100-3.

4. Thwaites CL, Lundeg G, Dondorp AM, sepsis in resource-limited settings-expert consensus recommendations group of the European Society of Intensive Care Medicine, the MahidolOxford Research Unit in Bangkok, Thailand. Recommendations for infection management in patients with sepsis and septic shock in resource-limited settings. Intensive Care Med. 2016;42(12):2040-2.

5. Martin GS, Mannino DM, Eaton S, Moss M. The epidemiology of sepsis in the United States from 1979 through 2000. N Engl J Med. 2003;348:1546-54.

6. Vincent JL, Sakr Y, Sprung CL, Ranieri VM, Reinhart K, Gerlach H, Moreno R, Carlet J, Le Gall JR, Payen D, Sepsis Occurrence in Acutely Ill Patients Investigators. Sepsis in European intensive care units: results of the SOAP study. Crit Care Med. 2006;34:344-53.

7. Phua J, Koh Y, Du B, Tang YQ, Divatia JV, Tan CC, Gomersall CD, Faruq MO, Shrestha BR, Gia Binh N, Arabi YM, Salahuddin N, Wahyuprajitno B, Tu ML, Wahab AY, Hameed AA, Nishimura M, Procyshyn M, Chan YH, MOSAICS Study Group. Management of severe sepsis in patients admitted to Asian intensive care units: prospective cohort study. BMJ. 2011;342:d3245.

8. Murthy S, Leligdowicz A, Adhikari NK. Intensive care unit capacity in low-income countries: a systematic review. PLoS One. 2015;10:e0116949.

9. Cheng AC, West TE, Limmathurotsakul D, Peacock SJ. Strategies to reduce mortality from bacterial sepsis in adults in developing countries. PLoS Med. 2008;5:e175. 
10. GBD 2013 Mortality and Causes of Death Collaborators. Global, regional, and national agesex specific all-cause and cause-specific mortality for 240 causes of death, 1990-2013: a systematic analysis for the Global Burden of Disease Study 2013. Lancet. 2015;385:117-71.

11. Global Burden of Disease Study 2013 Collaborators. Global, regional, and national incidence, prevalence, and years lived with disability for 301 acute and chronic diseases and injuries in 188 countries, 1990-2013: a systematic analysis for the Global Burden of Disease Study 2013. Lancet. 2015;386:743-800.

12. GBD 2015 Mortality and Causes of Death Collaborators. Global, regional, and national life expectancy, all-cause mortality, and cause-specific mortality for 249 causes of death, 1980-2015: a systematic analysis for the Global Burden of Disease Study 2015. Lancet. 2016;388:1459-544.

13. Rosenthal VD, Bijie H, Maki DG, Mehta Y, Apisarnthanarak A, Medeiros EA, Leblebicioglu H, Fisher D, Alvarez-Moreno C, Khader IA, Del Rocio Gonzalez Martinez M, Cuellar LE, Navoa-Ng JA, Abouqal R, Guanche Garcell H, Mitrev Z, Pirez Garcia MC, Hamdi A, Duenas L, Cancel E, Gurskis V, Rasslan O, Ahmed A, Kanj SS, Ugalde OC, Mapp T, Raka L, Yuet Meng C, le Thu TA, Ghazal S, Gikas A, Narvaez LP, Mejia N, Hadjieva N, Gamar Elanbya MO, Guzman Siritt ME, Jayatilleke K, INICC members. International Nosocomial Infection Control Consortium (INICC) report, data summary of 36 countries, for 2004-2009. Am J Infect Control. 2012;40:396-407.

14. Frikha N, Mebazaa M, Mnif L, El Euch N, Abassi M, Ben Ammar MS. Septic shock in a Tunisian intensive care unit: mortality and predictive factors. 100 cases. Tunis Med. 2005;83:320-5.

15. Jacob ST, Moore CC, Banura P, Pinkerton R, Meya D, Opendi P, Reynolds SJ, Kenya-Mugisha N, Mayanja-Kizza H, Scheld WM, Promoting Resource-Limited Interventions for Sepsis Management in Uganda Study Group. Severe sepsis in two Ugandan hospitals: a prospective observational study of management and outcomes in a predominantly HIV-1 infected population. PLoS One. 2009;4:e7782.

16. Siddiqui S. Not "surviving sepsis" in the developing countries. J Indian Med Assoc. 2007; 105:221.

17. Dunser MW, Bataar O, Tsenddorj G, Lundeg G, Torgersen C, Romand JA, Hasibeder WR, Helfen Beruhrt Study Team. Differences in critical care practice between an industrialized and a developing country. Wien Klin Wochenschr. 2008;120:600-7.

18. Vernet G, Mary C, Altmann DM, Doumbo O, Morpeth S, Bhutta ZA, Klugman KP. Surveillance for antimicrobial drug resistance in under-resourced countries. Emerg Infect Dis. 2014;20:434-41.

19. Laxminarayan R, Matsoso P, Pant S, Brower C, Rottingen JA, Klugman K, Davies S. Access to effective antimicrobials: a worldwide challenge. Lancet. 2016;387:168-75.

20. Bone RC, Balk RA, Cerra FB, Dellinger RP, Fein AM, Knaus WA, Schein RM, Sibbald WJ. Definitions for sepsis and organ failure and guidelines for the use of innovative therapies in sepsis. The ACCP/SCCM Consensus Conference Committee. American College of Chest Physicians/Society of Critical Care Medicine. Chest. 1992;101:1644-55.

21. Levy MM, Fink MP, Marshall JC, Abraham E, Angus D, Cook D, Cohen J, Opal SM, Vincent JL, Ramsay G, International Sepsis Definitions Conference. 2001 SCCM/ ESICM/ACCP/ATS/SIS International Sepsis Definitions Conference. Intensive Care Med. 2003;29:530-8.

22. Kissoon N, Daniels R, van der Poll T, Finfer S, Reinhart K. Sepsis-the final common pathway to death from multiple organ failure in infection. Crit Care Med. 2016;44:e446.

23. Auma MA, Siedner MJ, Nyehangane D, Nalusaji A, Nakaye M, Mwanga-Amumpaire J, Muhindo R, Wilson LA, Boum Y II, Moore CC. Malaria is an uncommon cause of adult sepsis in south-western Uganda. Malar J. 2013;12:146.

24. White NJ, Pukrittayakamee S, Hien TT, Faiz MA, Mokuolu OA, Dondorp AM. Malaria. Lancet. 2014;383:723-35.

25. White NJ, Turner GD, Day NP, Dondorp AM. Lethal malaria: Marchiafava and Bignami were right. J Infect Dis. 2013;208:192-8. 
26. Chen Y, Maguire T, Hileman RE, Fromm JR, Esko JD, Linhardt RJ, Marks RM. Dengue virus infectivity depends on envelope protein binding to target cell heparan sulfate. Nat Med. 1997;3:866-71.

27. Avirutnan P, Zhang L, Punyadee N, Manuyakorn A, Puttikhunt C, Kasinrerk W, Malasit P, Atkinson JP, Diamond MS. Secreted NS1 of dengue virus attaches to the surface of cells via interactions with heparan sulfate and chondroitin sulfate E. PLoS Pathog. 2007;3:e183.

28. Adhikari NK, Fowler RA, Bhagwanjee S, Rubenfeld GD. Critical care and the global burden of critical illness in adults. Lancet. 2010;376:1339-46.

29. Haniffa R, De Silva AP, Iddagoda S, Batawalage H, De Silva ST, Mahipala PG, Dondorp A, de Keizer N, Jayasinghe S. A cross-sectional survey of critical care services in Sri Lanka: a lower middle-income country. J Crit Care. 2014;29:764-8.

30. Mendsaikhan N, Begzjav T, Lundeg G, Brunauer A, Dunser MW. A nationwide census of ICU capacity and admissions in Mongolia. PLoS One. 2016;11:e0160921.

31. Jochberger S, Ismailova F, Lederer W, Mayr VD, Luckner G, Wenzel V, Ulmer H, Hasibeder WR, Dunser MW; "Helfen Beruhrt" Study Team. Anesthesia and its allied disciplines in the developing world: a nationwide survey of the Republic of Zambia. Anesth Analg. 2008;106:942-948, table of contents

32. Kwizera A, Dunser M, Nakibuuka J. National intensive care unit bed capacity and ICU patient characteristics in a low income country. BMC Res Notes. 2012;5:475.

33. Campos-Mino S, Sasbon JS, von Dessauer B. Pediatric intensive care in Latin America. Med Intensiva. 2012;36:3-10.

34. Kissoon N. Sepsis care differences unlike beauty are not skin deep. Pediatr Crit Care Med. 2016;17:568-9.

35. Divatia JV, Amin PR, Ramakrishnan N, Kapadia FN, Todi S, Sahu S, Govil D, Chawla R, Kulkarni AP, Samavedam S, Jani CK, Rungta N, Samaddar DP, Mehta S, Venkataraman R, Hegde A, Bande BD, Dhanuka S, Singh V, Tewari R, Zirpe K, Sathe P, INDICAPS Study Investigators. Intensive care in India: the Indian intensive care case mix and practice patterns study. Indian J Crit Care Med. 2016;20:216-25.

36. Austin S, Murthy S, Wunsch H, Adhikari NK, Karir V, Rowan K, Jacob ST, Salluh J, Bozza FA, Du B, An Y, Lee B, Wu F, Nguyen YL, Oppong C, Venkataraman R, Velayutham V, Duenas $\mathrm{C}$, Angus DC, International Forum of Acute Care Trialists. Access to urban acute care services in high- vs. middle-income countries: an analysis of seven cities. Intensive Care Med. 2014;40:342-52.

37. Marshall JC, Bosco L, Adhikari NK, Connolly B, Diaz JV, Dorman T, Fowler RA, Meyfroidt G, Nakagawa S, Pelosi P, Vincent JL, Vollman K, Zimmerman J. What is an intensive care unit? A report of the task force of the World Federation of Societies of Intensive and Critical Care Medicine. J Crit Care. 2017;37:270-6.

38. Rhodes A, Ferdinande P, Flaatten H, Guidet B, Metnitz PG, Moreno RP. The variability of critical care bed numbers in Europe. Intensive Care Med. 2012;38:1647-53.

39. Baelani I, Jochberger S, Laimer T, Otieno D, Kabutu J, Wilson I, Baker T, Dunser MW. Availability of critical care resources to treat patients with severe sepsis or septic shock in Africa: a self-reported, continent-wide survey of anaesthesia providers. Crit Care. 2011;15:R10.

40. Baker T, Lugazia E, Eriksen J, Mwafongo V, Irestedt L, Konrad D. Emergency and critical care services in Tanzania: a survey of ten hospitals. BMC Health Serv Res. 2013;13:140.

41. Bataar O, Lundeg G, Tsenddorj G, Jochberger S, Grander W, Baelani I, Wilson I, Baker T, Dunser MW, Helfen Beruhrt Study Team. Nationwide survey on resource availability for implementing current sepsis guidelines in Mongolia. Bull World Health Organ. 2010;88:839-46.

42. Hsia RY, Mbembati NA, Macfarlane S, Kruk ME. Access to emergency and surgical care in sub-Saharan Africa: the infrastructure gap. Health Policy Plan. 2012;27:234-44.

43. Arabi YM, Phua J, Koh Y, Du B, Faruq MO, Nishimura M, Fang WF, Gomersall C, Al Rahma HN, Tamim H, Al-Dorzi HM, Al-Hameed FM, Adhikari NK, Sadat M, Asian Critical Care Clinical Trials Group. Structure, organization, and delivery of critical care in Asian ICUs. Crit Care Med. 2016;44:e940-8. 
44. Dondorp AM, Iyer SS, Schultz MJ. Critical care in resource-restricted settings. JAMA. 2016;315:753-4.

45. Mendsaikhan N, Begzjav T, Lundeg G, Dünser MW. Potentially preventable deaths by intensive care medicine in Mongolian hospitals. Crit Care Res Pract. 2016; https://doi. org/10.1155/2016/8624035.

46. Cubro H, Somun-Kapetanovic R, Thiery G, Talmor D, Gajic O. Cost effectiveness of intensive care in a low resource setting: a prospective cohort of medical critically ill patients. World $\mathrm{J}$ Crit Care Med. 2016;5:150-64.

47. Phua J, Joynt GM, Nishimura M, Deng Y, Myatra SN, Chan YH, Binh NG, Tan CC, Faruq MO, Arabi YM, Wahjuprajitno B, Liu SF, Hashemian SM, Kashif W, Staworn D, Palo JE, Koh Y, ACME Study Investigators; Asian Critical Care Clinical Trials Group. Withholding and withdrawal of life-sustaining treatments in low-middle-income versus high-income Asian countries and regions. Intensive Care Med. 2016;42:1118-27.

48. Kissoon N. Healthcare costs to poor families: an agonising burden. Indian J Pediatr. 2016;83:1063-4.

49. Dunser MW, Festic E, Dondorp A, Kissoon N, Ganbat T, Kwizera A, Haniffa R, Baker T, Schultz MJ, Global Intensive Care Working Group of European Society of Intensive Care Medicine. Recommendations for sepsis management in resource-limited settings. Intensive Care Med. 2012;38:557-74.

50. Dellinger RP, Levy MM, Rhodes A, Annane D, Gerlach H, Opal SM, Sevransky JE, Sprung CL, Douglas IS, Jaeschke R, Osborn TM, Nunnally ME, Townsend SR, Reinhart K, Kleinpell RM, Angus DC, Deutschman CS, Machado FR, Rubenfeld GD, Webb SA, Beale RJ, Vincent JL, Moreno R, Surviving Sepsis Campaign Guidelines Committee including the Pediatric Subgroup. Surviving sepsis campaign: international guidelines for management of severe sepsis and septic shock: 2012. Crit Care Med. 2013;41:580-637.

51. Halpern NA, Pastores SM, Greenstein RJ. Critical care medicine in the United States 19852000: an analysis of bed numbers, use, and costs. Crit Care Med. 2004;32:1254-9.

52. Pinsky MR. Understanding costs and cost-effectiveness in critical care: report from the second American Thoracic Society workshop on outcomes research. Am J Respir Crit Care Med. 2002;165:540-50.

53. Shann F. Role of intensive care in countries with a high child mortality rate. Pediatr Crit Care Med. 2011;12:114-5.

54. Approximating the GNI per capita used to differentiate between a lower-middle and uppermiddle income country by the World Bank. https://datahelpdesk.worldbank.org/knowledgebase/articles/906519-worldbank-country-and-lending-groups. Accessed 14 Mar 2017.

55. Assuncao MS, Teich V, Shiramizo SC, Araujo DV, Carrera RM, Serpa Neto A, Silva E. The costeffectiveness ratio of a managed protocol for severe sepsis. J Crit Care. 2014;29(692):e691-6.

56. Harrison M, Collins CD. Is procalcitonin-guided antimicrobial use cost-effective in adult patients with suspected bacterial infection and sepsis? Infect Control Hosp Epidemiol. 2015;36:265-72.

57. Huang DT, Clermont G, Dremsizov TT, Angus DC, Pro CI. Implementation of early goaldirected therapy for severe sepsis and septic shock: a decision analysis. Crit Care Med. 2007;35:2090-100.

58. Jones AE, Troyer JL, Kline JA. Cost-effectiveness of an emergency department-based early sepsis resuscitation protocol. Crit Care Med. 2011;39:1306-12.

59. Karlsson S, Ruokonen E, Varpula T, Ala-Kokko TI, Pettila V, Finnsepsis Study Group. Long-term outcome and quality-adjusted life years after severe sepsis. Crit Care Med. 2009;37:1268-74.

60. Lehmann LE, Herpichboehm B, Kost GJ, Kollef MH, Stuber F. Cost and mortality prediction using polymerase chain reaction pathogen detection in sepsis: evidence from three observational trials. Crit Care. 2010;14:R186.

61. Talmor D, Greenberg D, Howell MD, Lisbon A, Novack V, Shapiro N. The costs and costeffectiveness of an integrated sepsis treatment protocol. Crit Care Med. 2008;36:1168-74. 
62. Suarez D, Ferrer R, Artigas A, Azkarate I, Garnacho-Montero J, Goma G, Levy MM, Ruiz JC, Edusepsis Study Group. Cost-effectiveness of the Surviving Sepsis Campaign protocol for severe sepsis: a prospective nation-wide study in Spain. Intensive Care Med. 2011;37:444-52.

63. Negrini D, Sheppard L, Mills GH, Jacobs P, Rapoport J, Bourne RS, Guidet B, Csomos A, Prien T, Anderson G, Edbrooke DL. International Programme for Resource Use in Critical Care (IPOC) - a methodology and initial results of cost and provision in four European countries. Acta Anaesthesiol Scand. 2006;50:72-9.

64. Tan SS, Bakker J, Hoogendoorn ME, Kapila A, Martin J, Pezzi A, Pittoni G, Spronk PE, Welte R, Hakkaart-van Roijen L. Direct cost analysis of intensive care unit stay in four European countries: applying a standardized costing methodology. Value Health. 2012;15:81-6.

65. Dräger S, Dal Poz MR, Evans DB. Health workers wages: an overview from selected countries. Geneva: WHO; 2006.

66. Parikh CR, Karnad DR. Quality, cost, and outcome of intensive care in a public hospital in Bombay, India. Crit Care Med. 1999;27:1754-9.

67. Kulkarni AP, Divatia JV. A prospective audit of costs of intensive care in cancer patients in India. Indian J Crit Care Med. 2013;17:292-7.

68. Riviello ED, Kiviri W, Fowler RA, Mueller A, Novack V, Banner-Goodspeed VM, Weinkauf JL, Talmor DS, Twagirumugabe T. Predicting mortality in low-income country ICUs: the Rwanda Mortality Probability Model (R-MPM). PLoS One. 2016;11:e0155858.

69. Haniffa R, Lubell Y, Cooper BS, Mohanty S, Shamsul A, Karki A, Pattnaik R, Maswood A, Pangeni R, Schultz MJ, Dondorp AM. Impact of a structured ICU training programme in resource-limited settings in Asia. PLoS One. 2017; https://doi.org/10.1371/journal. pone.0173483.

70. Penno EC, Baird SJ, Crump JA. Cost-effectiveness of surveillance for bloodstream infections for sepsis management in low-resource settings. Am J Trop Med Hyg. 2015;93:850-60.

71. Thukral A, Lodha R, Irshad M, Arora NK. Performance of Pediatric Risk of Mortality (PRISM), Pediatric Index of Mortality (PIM), and PIM2 in a pediatric intensive care unit in a developing country. Pediatr Crit Care Med. 2006;7:356-61.

72. Hutchings A, Durand MA, Grieve R, Harrison D, Rowan K, Green J, Cairns J, Black N. Evaluation of modernisation of adult critical care services in England: time series and cost effectiveness analysis. BMJ. 2009;339:b4353.

73. Rahman M, Fukui T. Biomedical publication-global profile and trend. Public Health. 2003;117:274-80.

74. Bellani G, Laffey JG, Pham T, Fan E, Brochard L, Esteban A, Gattinoni L, van Haren F, Larsson A, McAuley DF, Ranieri M, Rubenfeld G, Thompson BT, Wrigge H, Slutsky AS, Pesenti A, LUNG SAFE Investigators; ESICM Trials Group. Epidemiology, patterns of care, and mortality for patients with acute respiratory distress syndrome in intensive care units in 50 countries. JAMA. 2016;315:788-800.

75. Fleischmann C, Scherag A, Adhikari NK, Hartog CS, Tsaganos T, Schlattmann P, Angus DC, Reinhart K, International Forum of Acute Care Tialists. Assessment of global incidence and mortality of hospital-treated sepsis. Current estimates and limitations. Am J Respir Crit Care Med. 2016;193:259-72.

76. Vincent JL, Marshall JC, Namendys-Silva SA, Francois B, Martin-Loeches I, Lipman J, Reinhart K, Antonelli M, Pickkers P, Njimi H, Jimenez E, Sakr Y, ICON investigators. Assessment of the worldwide burden of critical illness: the intensive care over nations (ICON) audit. Lancet Respir Med. 2014;2:380-6.

77. Kang KT, Chandler HK, Espinosa V, Kissoon N. Systems for paediatric sepsis: a global survey. West Indian Med J. 2014;63:703-10.

78. ISARIC. International Severe Acute Respiratory and Emerging Infection Consortium. 2016. https://isaric.tghn.org/about/

79. Ashley EA, Dhorda M, Fairhurst RM, Amaratunga C, Lim P, Suon S, Sreng S, Anderson JM, Mao S, Sam B, Sopha C, Chuor CM, Nguon C, Sovannaroth S, Pukrittayakamee S, Jittamala P, Chotivanich K, Chutasmit K, Suchatsoonthorn C, Runcharoen R, Hien TT, Thuy-Nhien NT, Thanh NV, Phu NH, Htut Y, Han KT, Aye KH, Mokuolu OA, Olaosebikan RR, Folaranmi OO, 
Mayxay M, Khanthavong M, Hongvanthong B, Newton PN, Onyamboko MA, Fanello CI, Tshefu AK, Mishra N, Valecha N, Phyo AP, Nosten F, Yi P, Tripura R, Borrmann S, Bashraheil M, Peshu J, Faiz MA, Ghose A, Hossain MA, Samad R, Rahman MR, Hasan MM, Islam A, Miotto O, Amato R, MacInnis B, Stalker J, Kwiatkowski DP, Bozdech Z, Jeeyapant A, Cheah PY, Sakulthaew T, Chalk J, Intharabut B, Silamut K, Lee SJ, Vihokhern B, Kunasol C, Imwong M, Tarning J, Taylor WJ, Yeung S, Woodrow CJ, Flegg JA, Das D, Smith J, Venkatesan M, Plowe CV, Stepniewska K, Guerin PJ, Dondorp AM, Day NP, White NJ, Tracking Resistance to Artemisinin Collaboration. Spread of artemisinin resistance in Plasmodium falciparum malaria. N Engl J Med. 2014;371:411-23.

80. Chantratita N, Tandhavanant S, Myers ND, Seal S, Arayawichanont A, Kliangsa-Ad A, Hittle LE, Ernst RK, Emond MJ, Wurfel MM, Day NP, Peacock SJ, West TE. Survey of innate immune responses to Burkholderia pseudomallei in human blood identifies a central role for lipopolysaccharide. PLoS One. 2013;8:e81617.

81. Desjardins CA, Cohen KA, Munsamy V, Abeel T, Maharaj K, Walker BJ, Shea TP, Almeida DV, Manson AL, Salazar A, Padayatchi N, O'Donnell MR, Mlisana KP, Wortman J, Birren BW, Grosset J, Earl AM, Pym AS. Genomic and functional analyses of Mycobacterium tuberculosis strains implicate ald in D-cycloserine resistance. Nat Genet. 2016;48:544-51.

82. Kim JY, Farmer P, Porter ME. Redefining global health-care delivery. Lancet. 2013;382:1060-9.

83. Scott KW, Jha AK. Putting quality on the global health agenda. N Engl J Med. 2014;371:3-5.

84. Binagwaho A, Kyamanywa P, Farmer PE, Nuthulaganti T, Umubyeyi B, Nyemazi JP, Mugeni SD, Asiimwe A, Ndagijimana U, Lamphere McPherson H, Ngirabega Jde D, Sliney A, Uwayezu A, Rusanganwa V, Wagner CM, Nutt CT, Eldon-Edington M, Cancedda C, Magaziner IC, Goosby E. The human resources for health program in Rwanda-new partnership. N Engl J Med. 2013;369:2054-9.

85. Vukoja M, Kashyap R, Gavrilovic S, Dong Y, Kilickaya O, Gajic O. Checklist for early recognition and treatment of acute illness: international collaboration to improve critical care practice. World J Crit Care Med. 2015;4:55-61.

86. Baker T, Schell CO, Lugazia E, Blixt J, Mulungu M, Castegren M, Eriksen J, Konrad D. Vital signs directed therapy: improving care in an intensive care unit in a low-income country. PLoS One. 2015;10:e144801.

87. Riviello ED, Kiviri W, Twagirumugabe T, Mueller A, Banner-Goodspeed VM, Officer L, Novack V, Mutumwinka M, Talmor DS, Fowler RA. Hospital incidence and outcomes of the acute respiratory distress syndrome using the Kigali modification of the Berlin definition. Am J Respir Crit Care Med. 2016;193:52-9.

88. Chu KM, Jayaraman S, Kyamanywa P, Ntakiyiruta G. Building research capacity in Africa: equity and global health collaborations. PLoS Med. 2014;11:e1001612.

89. Singer M, Deutschman CS, Seymour CW, Shankar-Hari M, Annane D, Bauer M, Bellomo R, Bernard GR, Chiche JD, Coopersmith CM, Hotchkiss RS, Levy MM, Marshall JC, Martin GS, Opal SM, Rubenfeld GD, van der Poll T, Vincent JL, Angus DC. The third international consensus definitions for sepsis and septic shock (Sepsis-3). JAMA. 2016;315:801-10.

90. Arabi YM, Schultz MJ, Salluh JI. Intensive care medicine in 2050: global perspectives. Intensive Care Med. 2016;43(11):1695-9.

91. Maitland K, Kiguli S, Opoka RO, Engoru C, Olupot-Olupot P, Akech SO, Nyeko R, Mtove G, Reyburn H, Lang T, Brent B, Evans JA, Tibenderana JK, Crawley J, Russell EC, Levin M, Babiker AG, Gibb DM, FEAST Trial Group. Mortality after fluid bolus in African children with severe infection. N Engl J Med. 2011;364:2483-95.

92. Riviello ED, Letchford S, Cook EF, Waxman AB, Gaziano T. Improving decision making for massive transfusions in a resource poor setting: a preliminary study in Kenya. PLoS One. 2015;10:e0127987.

93. Leligdowicz A, Fischer WA II, Uyeki TM, Fletcher TE, Adhikari NK, Portella G, Lamontagne F, Clement C, Jacob ST, Rubinson L, Vanderschuren A, Hajek J, Murthy S, Ferri M, Crozier I, Ibrahima E, Lamah MC, Schieffelin JS, Brett-Major D, Bausch DG, Shindo N, Chan AK, 
O’Dempsey T, Mishra S, Jacobs M, Dickson S, Lyon GM III, Fowler RA. Ebola virus disease and critical illness. Crit Care. 2016;20:217.

94. Buist AS, Parry V. The American Thoracic Society methods in epidemiologic, clinical, and operations research program. A research capacity-building program in low- and middleincome countries. Ann Am Thorac Soc. 2013;10:281-9.

95. Howitt P, Darzi A, Yang GZ, Ashrafian H, Atun R, Barlow J, Blakemore A, Bull AM, Car J, Conteh L, Cooke GS, Ford N, Gregson SA, Kerr K, King D, Kulendran M, Malkin RA, Majeed A, Matlin S, Merrifield R, Penfold HA, Reid SD, Smith PC, Stevens MM, Templeton MR, Vincent C, Wilson E. Technologies for global health. Lancet. 2012;380:507-35.

Open Access This chapter is licensed under the terms of the Creative Commons Attribution 4.0 International License (http://creativecommons.org/licenses/by/4.0/), which permits use, sharing, adaptation, distribution and reproduction in any medium or format, as long as you give appropriate credit to the original author(s) and the source, provide a link to the Creative Commons license and indicate if changes were made.

The images or other third party material in this chapter are included in the chapter's Creative Commons license, unless indicated otherwise in a credit line to the material. If material is not included in the chapter's Creative Commons license and your intended use is not permitted by statutory regulation or exceeds the permitted use, you will need to obtain permission directly from the copyright holder. 